\title{
UML-MОДЕЛЮВАННЯ СИСТЕМИ ПРИЙНЯТТЯ РІШЕНЬ В МЕДИЧНИХ НАУКОВИХ ДОСЛІДЖЕННЯХ
}

\author{
В. П. Марценюк, І. Є. Андрущак, О. М. Кучвара \\ ДВНЗ «Тернопільський державний медичний університет \\ імені І. Я. Горбачевського МОЗ України»
}

Проведено системний аналіз процесу підтримки прийняття рішень в системних медичних дослідженнях. Проаналізована структура системи. Виконані проектні дослідження із застосуванням сучасних UML-засобів, що дозволяють здійснити проектування та реалізацію програмного комплексу СППР.

Ключові слова: UML-моделювання, прийняття рішень, медичні наукові дослідження.

\section{UML-МОДЕЛИРОВАНИЕ СИСТЕМЫ ПРИНЯТИЯ РЕШЕНИЙ В МЕДИЦИНСКИХ НАУЧНЫХ ИССЛЕДОВАНИЯХ}

\author{
В. П. Марценюк, И. Е. Андрущак, А. М. Кучвара \\ ГВУз «Тернопольский государственный медицинский университет \\ имени И. Я. Горбачевского МЗ Украины»
}

\begin{abstract}
Проведен системный анализ процесса поддержки принятия решений в системных медицинских исследованиях. Проанализирована структура системы. Выполнены проектные исследования с использованием UML-средств, позволяющие осуществить проектную и программную реализацию программного комплекса СППР.
\end{abstract}

Ключевые слова: UML-моделирование, принятие решений, медицинские научные исследования

\section{UML-MODELLING OF DECISION SUPPORT SYSTEM FOR MEDICAL RESEARCH}

\author{
V. P. Martsenyuk, I. Ye. Andrushchak, O. M. Kuchvara \\ I. Ya. Horbachevsky Ternopii State Medical University
}

\begin{abstract}
There was fulfilled systems analysis of decision making process for systemic medical research. The structure of the system was analysed. There were executed project research with help of UML-tools, allowing to fulfill project and software implementation of decision support system.
\end{abstract}

Key words: UML-modeling, decision making, medical research.

Вступ. Значиме місце у вирішенні проблем національної охорони здоров'я посідає розвиток медичної науки. При цьому одним з основних способів подолання проблем у національних системах охорони здоров'я є використання потенціалу науковцівмедиків $з$ метою розробки і впровадження новітніх лікувальних, діагностичних і профілактичних методик, що сприяє підвищенню якості медичної допомоги й збереженню здоров'я населення.

У рамках розв'язання завдань, передбачених національними проектами, особливого значення набувають науково-практичні дослідження з інформаційного супроводу інноваційних лікувальних методик: моделювання розвитку захворювання під дією інноваційних лікувальних методик; порівняльний аналіз ефективності лікувальних методик; обгрунтування прийняття рішення при виборі тактики лікування; прогнозування фінансового забезпечення лікування, так необхідного в медичному страхуванні. Це далеко не повний перелік задач, які виникають при проведенні системних медичних досліджень з розробки та впровадження інноваційних лікувальних методик.

Аналіз математичних моделей 3 питань медичної наукової діяльності показує необхідність розробки математичного апарату методів прийняття систем- 
них рішень, оптимізації та керування. Вирішення проблем медичної інноваційної діяльності пов'язане із розробкою математичних моделей розвитку i поширення захворювань (у випадку епідеміологічного захворювання), опису їх перебігу (у випадку багатостадійності). Такі моделі використовують апарат як теорії диференціальних рівнянь, випадкових процесів, так і інформаційних систем, системного аналізу та прийняття рішень. їх практична реалізація вимагає розробки відповідного програмного середовища [1-14].

Мета і задачі дослідження. Мета роботи - розробити UML-модель системи підтримки прийняття рішень для основних задач системних медичних досліджень з урахуванням етіології захворювання та підтримкою медичного страхування.

Основна частина. Основною складовою об'єктноорієнтованого аналізу при розробці інформаційної системи є декомпозиція проблеми на окремі класи понять (концептуальні класи) або об'єкти.

Моделювання предметної області - це один із початкових етапів проектування системи, який потрібен для виявлення, класифікації і формалізації відомостей про всі аспекти предметної області, що визначають властивості системи, яка розробляється.

Опис предметної області системних медичних досліджень здійснено з використанням мови UML та інструментального засобу Visual Paradigm CE, інтегрованого в Netbeans ШЕ.

При моделюванні предметної області виходили 3 мети, що проектоване програмне середовище призначене для введення, збереження та обробки інформації про системні медичні дослідження.

Система повинна забезпечувати виконання таких основних функцій:

- збір та обробка первинної статистичної медичної інформації;

- розробка компартментних математичних моделей керування (моделі фармакодинаміки) на основі статистичних даних;

- розробка компартментних моделей фармакокінетики;

- розробка компартментних епідеміологічних моделей;

- прийняття рішень в задачах медичної діагностики та профілактики;

- кількісне прогнозування розвитку поширення епідемічних захворювань;

- прийняття рішень в задачах лікування;

- прийняття рішень про форму епідемічної кривої;
- розробка імунопрофілактичних заходів;

- розробка схем медичного страхування.

Основні функції фактично описують технічне завдання даної системи.

Дійові особи. Вибір категорій користувачів системи, як правило, здійснюється неформально. При виборі дійових осіб ми користувалися ознаками:

- користувачі беруть участь в різних (незалежних) бізнес-процесах;

- користувачі мають різні права на виконання дій i доступ до інформації;

- користувачі взаємодіють із системою в різних режимах: від випадку до випадку, регулярно, постійно.

Грунтуючись на таких ознаках ми приходимо до таких категорій користувачів в першому наближенні:

- медичні науковці-теоретики - науковці, що працюють з моделями експериментальних захворювань, розроблених, як правило, для лабораторних тварин;

- медичні науковці-клініцисти - науковці, які працюють $з$ моделями захворювань, розроблених для пацієнтів;

- епідеміологи - науковці, які працюють 3 епідеміологічними моделями і статистичними даними, розробляють діаграми перехідних станів;

- системні аналітики - науковці, які розробляють математичні моделі, здійснюють їх кількісне та якісне дослідження;

- експериментальні науково-дослідні лабораторії (ЕНДЛ) - фахівці ЕНДЛ, які працюють над збором, зберіганням та первинною обробкою статистичних даних експериментальних досліджень;

- клінічні науково-дослідні лабораторії (КНДЛ) фахівці КНДЛ, що працюють над збором, зберіганням та первинною обробкою статистичних даних клінічних досліджень;

- санітарно-епідеміологічна служба (CEC) фахівці СЕС, що працюють над збором, зберіганням та первинною обробкою статистичних даних про поширення епідемічних захворювань;

- страховики - це страхові організації (компанії), які отримали ліцензію на право здійснювати медичне страхування і розробляють схеми медичного страхування.

У представленні діаграми використання програмного середовища системних медичних досліджень використано такі позначення: медичний науковецьтеоретик має ім'я Researcher-Theorist, медичний науковець-клініцист - Researcher-Clinician, епідеміолог - Epidemiologist, системний аналітик - Systems Analyst, спеціаліст ЕНДЛ - Experimental Laboratory 
Assistant, спеціаліст КНДЛ - Clinical Laboratory Assistant, спеціаліст CEC - Epidemic Service Officer, страховик - Insurer.

Варіанти використання. Аналіз технічного завдання дозволяє виділити такі варіанти використання:

- збір статистичної інформації ЕНДЛ;

- збір статистичної інформації КНДЛ;

- збір статистичної епідемічної інформації;

- обробка статистичної інформації ЕНДЛ (оцінки параметрів);

- обробка статистичної інформації КНДЛ (оцінки параметрів);

- обробка статистичної епідемічної інформації (оцінки парметрів);

- розробка компартментних математичних моделей;

- кількісне прогнозування на основі компартментих моделей;

- прийняття рішень в задачах лікування;

- прийняття рішень про форму епідемічної кривої;

- розробка імунопрофілактичних заходів;

- розробка схем медичного страхування.

Відношення на діаграмі використання. У першому наближенні в діаграмі використання використовуються два типи відношень: асоціаџія між дійовою особою і варіантом використання, яка показує, як дійова особа у той чи інший спосіб взаємодіє (надає вхідні дані, отримує результат) 3 варіантом використання; залежність між варіантами використання, яка показує, що один варіант використання залежить від іншого (в даному випадку залежність полягає у тому, що в певний сценарій незалежного варіанта використання може бути в певному місці вставлений в якості підпослідовності дій сценарій залежного варіанта використання - стереотип «include»).

Виходячи із того, як дійові особи беруть участь у сценаріях, що належать до певних варіантів використання, доцільно встановити асоціації:

- для системних аналітиків, дослідників-експериментальників, дослідників-клініцистів, епідеміологів 3 варіантами використання «розробка компартментних математичних моделей», «кількісне прогнозування», «прийняття рішень»;

- для фахівців експериментальних та клінічних науково-дослідних лабораторій, СЕС $з$ варіантами використання «збір статистичної інформації», «обробка статистичної інформації»;

- для страхувальників з варіантом використання «розробка схем медичного страхування».
До того ж, мають місце відношення залежності (стереотип include) між певними варіантами використання. Так, варіант використання «обробка статистичної інформації» залежить від «збір статистичної інформації»; варіант використання «розробка компартментних математичних моделей» залежить від «обробка статистичної інформації»; варіанти використання «кількісне прогнозування» та «прийняття рішень» залежать від «розробка компартментних математичних моделей».

Діаграма використання. Отже, якщо поглянемо надану модель використання із найзагальнішої точки зору, то бачимо, що в моделі є присутніми:

- внутрішня модельована система у формі набору варіантів використання, пов'язаних залежностями;

- зовнішне оточнення у формі дійових осіб;

- зв'язок між модельованою системою і зовнішнім оточенням у формі асоціацій між дійовими особами і варіантами використання (рис. 1). Внутрішня частина, виділена границями - суб'єкт.

Реалізація варіантів використання. Для кожного з варіантів використання метою є описати усі сценарії, що складають варіант використання. При цьому було використано діаграми двох типів - діаграми дії та діаграми послідовності.

При побудові діаграм використано мову потоку подій (flow of events). Так, потік подій для варіанта використання «збір експериментальної інформації» має вигляд:

1. SYSTEM Display login form

2. Login to the System. Click [OK]

3. SYSTEM Display Experimental Laboratory Assistant Form

4. loop

4.1. if it is necessary to add New Experimental Data

4.1.1. Click [New Experimental Data]

4.1.2. Select animal

4.1.2.1. Search animal by kind : String and id : int

4.1.2.2. Click [OK]

4.1.3. SYSTEM Display Animal Indices Form

4.1.4. Fill in Animal Indices Form

4.1.5. Click [Save] end if

4.2. if it is necessary to Edit Experimental Data

4.2.1. Click [Edit Experimental Data]

4.2.2. Select animal

4.2.2.1. Search animal by kind : String and id : int

4.2.2.2. Click [OK]

4.2.3. SYSTEM Display Animal Indices Form with indices

4.2.4. Edit indices in Animal Indices Form

4.2.5. Click [Save] end if until Experimental Laboratory Assistant Form is closed 


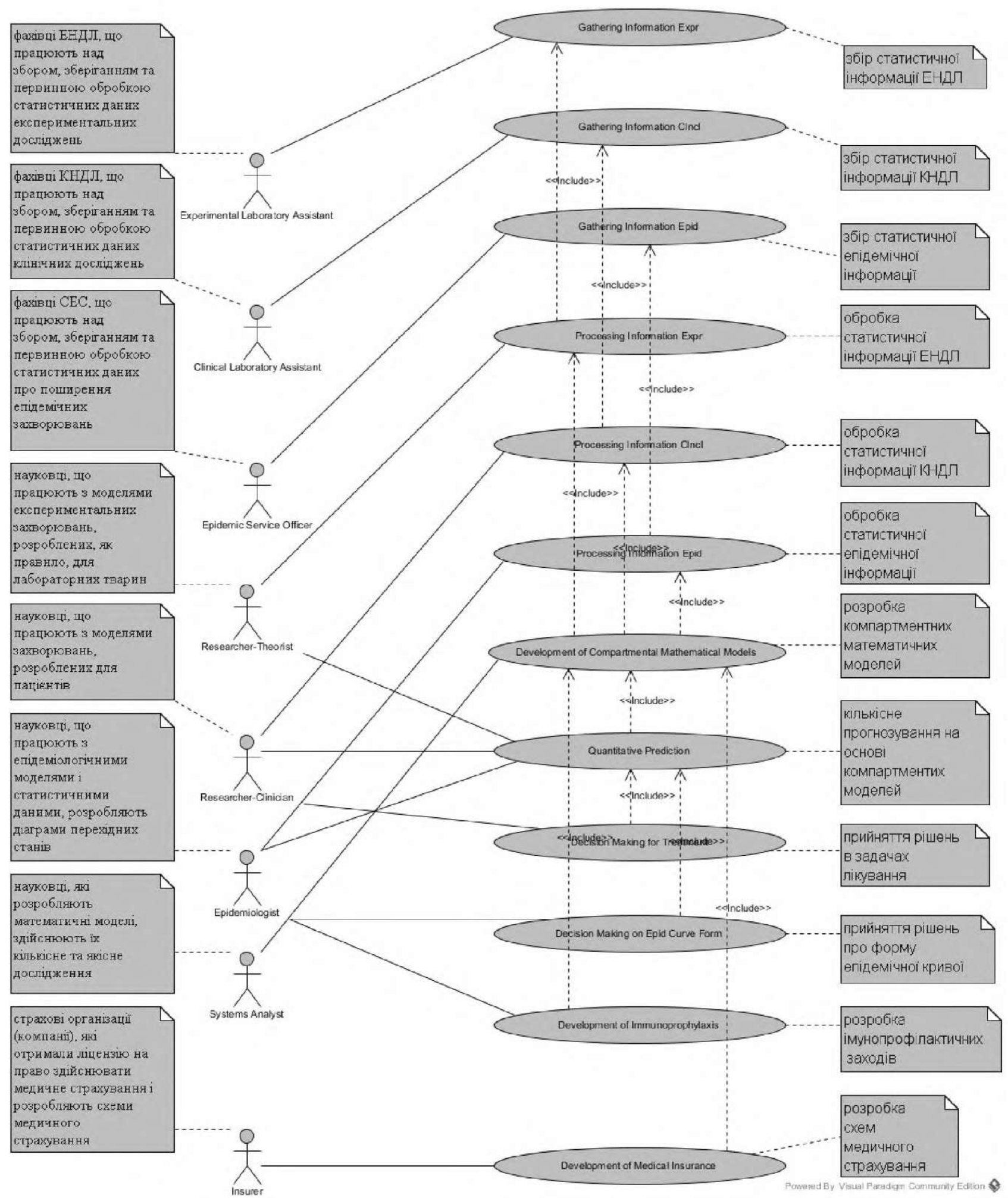

Puc. 1. Діаграма варіантів використання в програмному середовищі системних медичних досліджень.

При цьому діаграма послідовності подана на рисунку 2.

Таким же чином розроблено діаграму послідовності для варіанта використання «збір клінічної інформації».
Окремо зупинимося на роботі з епідемічними даними. Варіант використання «обробка статистичної епідемічної інформації» включає обчислення епідемічних порогів на основі попередньо накопиченої 
інформації в базі даних та побудову епідемічних кривих.

Розробка компартментної моделі включає побудову моделей з урахуванням одного або двох штамів вірусу.
Розробка заходів імунопрофілактики грунтується на попередньо розробленій компартментній моделі. До такої моделі повинні бути додані керування як інтенсивність імунопрофілактичних заходів та відповідні критерії якості.

sd Gathering_Information_Expr - Flow of Events )

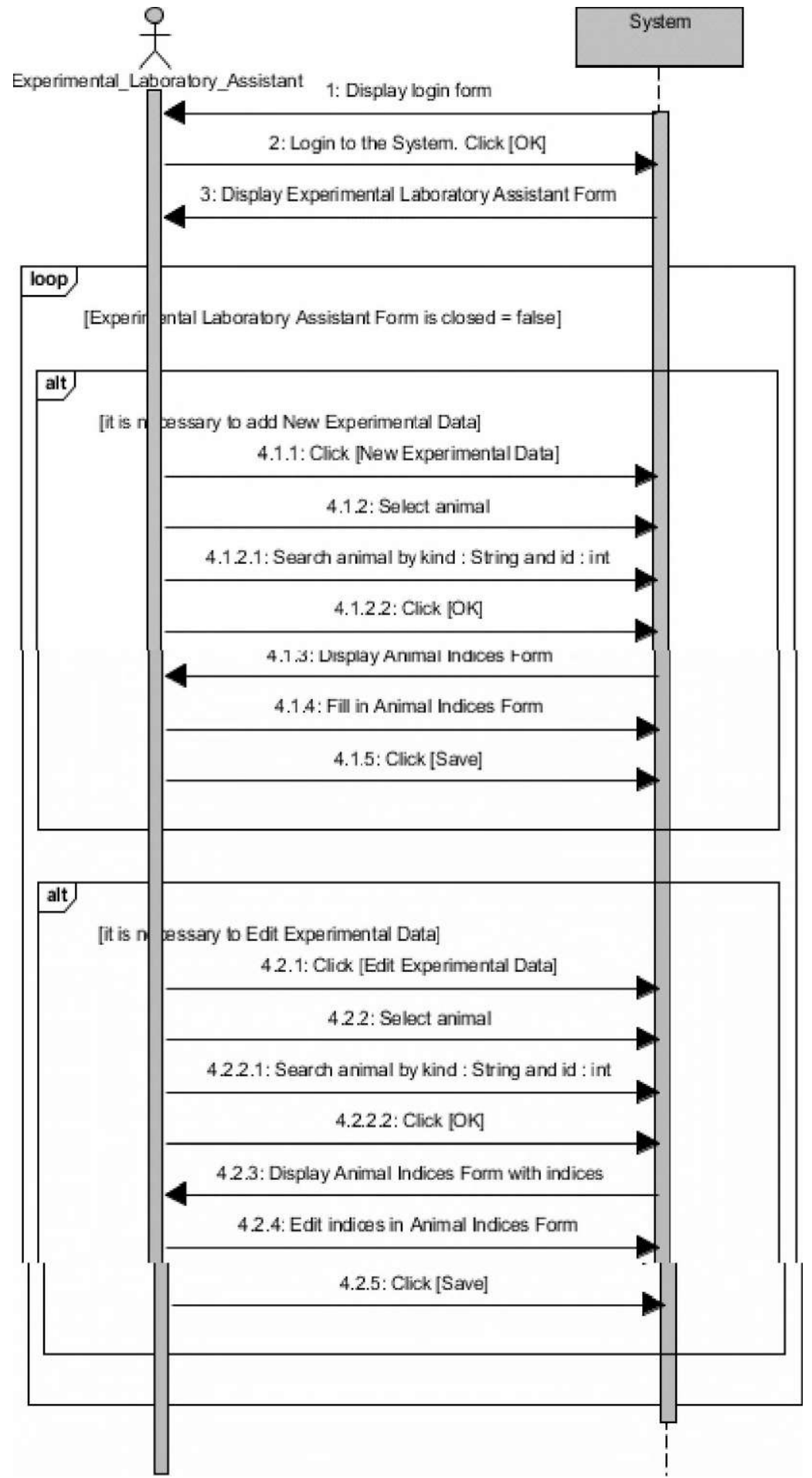

Puc. 2. Діаграма послідовності. 
Кількісне прогнозування на основі попередньо розробленої компартментної моделі починається 3 ідентифікації параметрів моделі. Далі застосовується алгоритм чисельного інтегрування рівнянь моделі.
Якісне прогнозування епідемічної кривої включає як дослідження стійкості ендемічних станів моделей методами Ляпунова, так і аналіз більш складних форм траєкторій (як наприклад прогнозування повторних спалахів) - за допомогою технології data mining, через побудову дерева рішень (рис. 3).

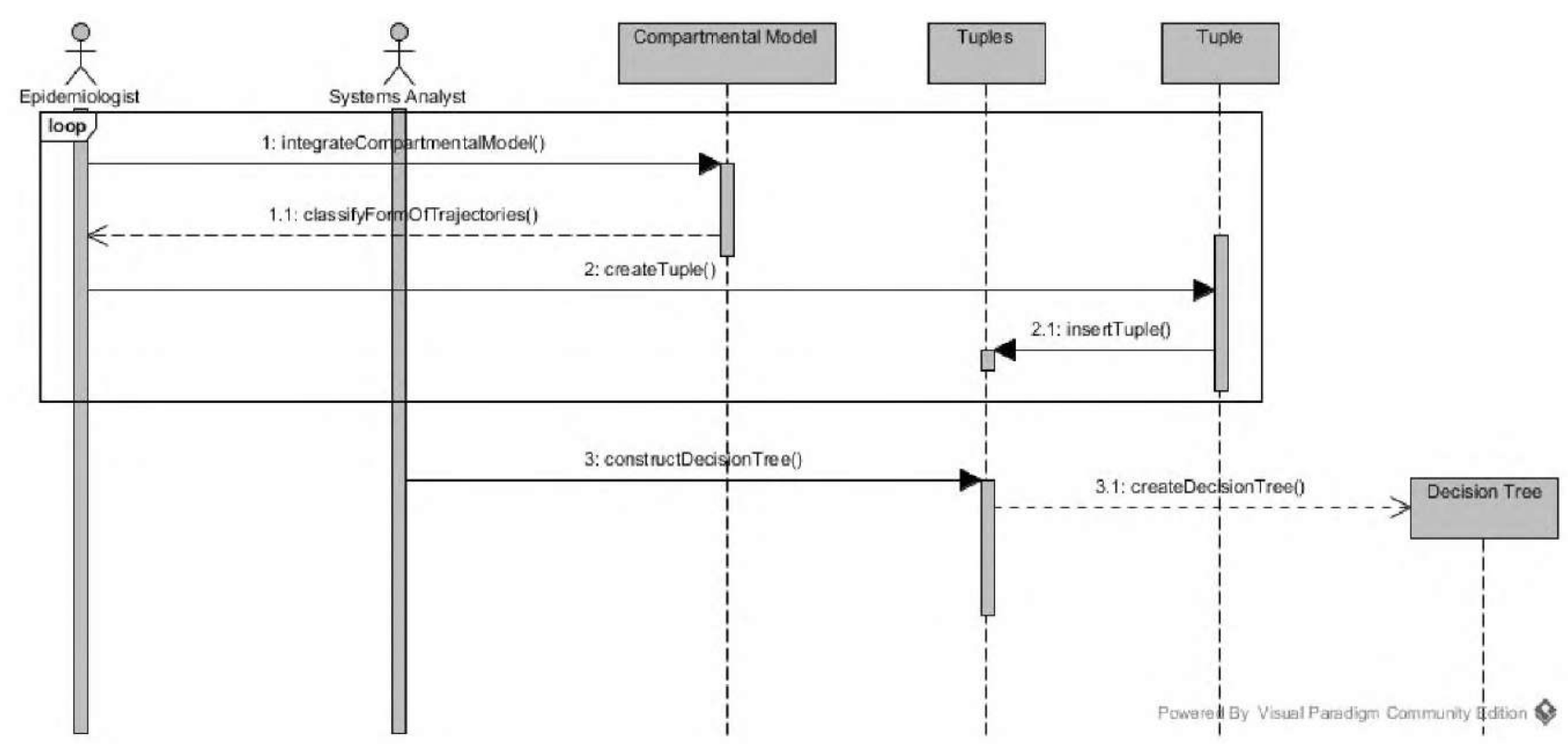

Puc. 3. Діаграма послідовності для побудови дерева рішень.

\section{Структурно-функціональна схема програмно-} го середовища підтримки прийняття рішень. Розроблене програмне середовище є насправді інформаційною системою підтримки прийняття рішень, призначеною для експлуатації в умовах науково-дослідної лабораторії медичних досліджень. Важливим завданням є прогнозування розвитку захворювання, а також розробка оптимальних схем лікування.

Побудована попередньо інформаційна модель використана при розробці системи підтримки прийняття рішення щодо роботи науково-дослідної лабораторіï.

Основні модулі системи підтримки прийняття рішення:

- вхідні дані;

- база даних;

- інтелектуальний аналіз;

- інтерпретація результатів;

- користувацький додаток.

Вхідні дані, що надходять до бази даних системних медичних досліджень, надаються працівниками лабораторій або СЕС.

Крім даних для побудови часових рядів база даних містить масиви даних 3 результатами імітаційного моделювання медико-біологічних процесів та якісними заключениями фахівців екмпериментальної та клінічної медицини, епідеміологів, що використовуватимуться для побудови структур знань.

Модуль інтелектуального аналізу даних складається з трьох основних блоків:

- блок аналізу;

- блок побудови моделей;

- інтерпретація результатів.

Підвищення ефективності лікувальних та профілактичних методик можна домогтися за рахунок застосування методів інтелектуального аналізу даних. Доцільним тут є використання засобів data mining, серед яких обрано метод індукції дерева рішень та алгоритм послідовного покриття.

Для вирішення поставлених задач найпродуктивнішим представляється використання даних методів в середовищі оперативної аналітичної обробки. На основі накопиченої інформації розроблено блок підтримки прийняття рішень інтелектуального аналізу даних, який для користувача представлений набором форм для розробки моделей, їх кількісного та якісного аналізу.

Підсистема інтелектуального аналізу даних у цьому випадку реалізується на основі розроблених компартментних моделей. Тому необхідною умовою для 
проведення аналізу є формування аналітичних метаданих для системи обробки.

Для оцінки чутливості і специфічності побудованих моделей була використана крос-перевірка (cross validation test), тобто метод оцінки моделі та її поведінки на незалежних даних. Для визначення класифікаційної цінності результуючої прогностичної моделі використовувалася ROC-крива 3 наступним визначенням площі під нею.

Для зручного застосування побудованих моделей та роботи з базою даних, з метою прийняття рішення щодо прогнозування захворювання та профілактичних заходів розроблено користувацький додаток, який містить форми для заповнення та відображення інформації про динаміку захворювання та якісного аналізу.

Якщо розглядати систему з точки зору користувача, то для нього найважливішими критеріями при роботі з даними є робота із зручним для користувача інтерфейсом, висока швидкість обробки даних, можливість налаштування системи під власні потреби $[20,22]$.

Класи та алгоритми, що забезпечують реалізацію визначених методів класів та програмний комплекс СППР системних медичних досліджень реалізовано у вигляді серверного додатка на мові Јava в інтег-

\section{Література}

1. Nakonechny O. G. Алгоритм побудови індукції дерева рішень $з$ використанням показника приросту інформації / O. G. Nakonechny, V. P. Martsenyuk, I. Y. Andrushchak // Комп'ютерно-інтегровані технології: освіта, наука, виробництво - Луцьк: Луцький НТУ. - 2015. - № 19. - Р. 49-52. 2. Martsenyuk V. P. Qualitative analysis of the antineoplastic immunity system on the basis of a decision tree/ V. P. Martsenyuk, I. Y. Andrushchak, I. S. Gvozdetska // Cybernetics and Systems Analysis. - 2015. - Vol. 51, № 3. p. $461^{\wedge} 170$.

3. Martsenyuk V. P. Constructing exponential estimates in compartmental systems with distributed delays: an approach based on the hale-lunel inequality / V. P. Martsenyuk, I. Y. Andrushchak, N. M. Gandzyuk // Cybernetics and Systems Analysis. - 2013. - Vol. 49, № 3. - P. 347-352.

4. Martsenyuk V. P. Construction of estimates of solutions in the model of antitumor immunity with impulse disturbances / V. P. Martsenyuk, O. A. Bahriy-Zayats // Journal of Automation and Infonnation Sciences. - 2013. - Vol. 45, № 10 . - P. 75-82.

5. Martsenyuk V. P. Stability estimation method for compartmental models with delay / V. P. Martsenyuk, N. M. Gandzyuk// Cybernetics and Systems Analysis.- 2013. -Vol. 49, № 1. - P. 81-85.
}

рованому середовищі розробкиNetbeans 7.0.1 та бази даних під керуваням СУБд MySQL.

Висновки. 1. Результати системного аналізу процесу підтримки прийняття рішень в системних медичних дослідженнях, аналіз структури системи та проектні дослідження, виконані із застосуванням сучасних UML-засобів, дозволяють здійснити проектування та реалізацію програмного комплексу СППР. СППР використовує сучасні алгоритми обробки даних та містить базу даних для збереження вхідних, внутрішніх та вихідних потоків даних і базу знань, що дає змогу об'єктивно оцінити стан процесу розвитку захворювання та вибрати оптимальні рішення щодо профілактики та лікування, які лежать в основі розробки схем медичного страхування.

2. Орієнтування на етапі проектування системи на UML-моделювання дає переваги об'єктної орієнтованості та автоматичної генерації коду, в результаті чого результати проектування є семантично близькими до методів програмування. До того ж, розроблена в такий спосіб система в подальшому підтримуватиме іiі реінжиніринг.

3. UML-моделювання вже на етапі проектування передбачає місце основних задач системи підтримки рішень в системних медичних дослідженнях та пов'язаних з ними математичних моделей та методів системного аналізу та прийняття рішень.

6. Martsenyuk V. P. Method of construction and detennination of approximate solutions of the model of phannacokinetics of nanoparticles / V. P. Martsenyuk, I. Y. Andrushchak, I. B. Melenchuk // Journal of Automation and Infonnation Sciences. - 2012. - Vol. 44, № 8. - P. 32^13.

7. Martsenyuk V. P. On the model of oncological disease for the stage residence time in accordance with the gompertz distribution / V. P. Martsenyuk, N. Y. Klymuk // Journal of Automation and Infonnation Sciences. - 2012. - Vol. 44, № 12 . - P. 68-75.

8. Martsenyuk V. P. On two-compartment phannacokinetic model with delay on the basis of the michaelis-menten dynamics: decomposition method / V. P. Martsenyuk, I. Y. Andrushchak // Journal of Automation and Infonnation Sciences. - 2009. - Vol. 41, № 8. - P. 24-37.

9. Nakonechny O. G. Uncertainties in medical processes control / O. G. Nakonechny, V. P. Martsenyuk // Coping with Uncertainty. Modeling and Policy Issues. - Springer Berlin Heidelberg, 2006. - P. 185-192.

10. Martsenyuk V. P. Qualitative analysis of human cells dynamics: stability, periodicity, bifurcations, control problems / V. P. Martsenyuk // Advances in Mathematics Researches. Volume 5 / G. Oyibo. - New York, New York, United States : Nova Science Publishers, Inc., 2005. - P. 137-200. 
МЕДИЧНА ІНФОРМАТИКА

TA ІНЖЕНЕРІЯ

11. Martsenyuk V. P. On stability of immune protection model with regard for damage of target organ: the degenerate liapunov functionals method/V. P. Martsenyuk// Cybernetics and Systems Analysis. - 2004. - Vol. 40, № 1. - P. 126-136. 12. Martsenyuk V. P. On generalized model of gompertzian dynamics / V. P. Martsenyuk // Journal of Automation and Infonnation Sciences. - 2004. - Vol. 36, № 12. - P. 51-60.
13. Martsenyuk V. P. Construction and study of stability of an antitumoral immunity model/V. P. Martsenyuk// Cybernetics and Systems Analysis. - 2004. - Vol. 40, № 5. - P. 778-783. 14. Martsenyuk V. P. Investigation of delay system with piecewise right side arising in radiotherapy / V. P. Martsenyuk, O. G. Nakonechny//WSEAS Transactions on Mathematics. -2004.-Vol. 3, № 1. - P. 181-187. 